\author{
Sandra Caban \\ ORCID: 0000-0002-5212-3630 \\ Uniwersytet Opolski
}

https://doi.org/10.19195/1642-5782.19(29).6

\title{
Ocena kompetencji komunikacyjnej dziecka z zespołem Aspergera (OKKA) własne narzędzie diagnostyczne
}

Kompetencja komunikacyjna obejmuje nie tylko wiedzę, ale przede wszystkim umiejętność wykonania językowego, czyli zdolność do używania języka w społeczeństwie. Autorki skali do badania kompetencji komunikacyjnej wśród dzieci, Maria Ligęza i Marta Białecka-Pikul, nazwały owe zdolności i wyjaśniły, na czym polegają:

— kompetencja lingwistyczna umożliwiająca rozumienie i budowanie zdań poprawnych pod względem gramatycznym;

- umiejętność poznawcza, która odpowiada za tworzenie oraz modyfikowanie wiedzy o świecie otaczającym człowieka;

— zdolność socjolingwistyczna polegająca na stosowaniu językowych i niejęzykowych norm narzuconych przez określoną grupę społeczną;

- zdolność interakcyjna obejmująca wiedzę oraz umiejętność stosowania werbalnych i niewerbalnych reguł dotyczących interakcji z drugim człowiekiem (na przykład zwrotów rozpoczynających i kończących rozmowę);

- zdolności funkcjonalno-regulacyjne, funkcjonalno-informacyjne, funkcjonalno-heurystyczne, funkcjonalno-ekspresywne mające na celu różnicowanie sposobu mówienia w zależności od potrzeb ludzi biorących udział w rozmowie ${ }^{1}$.

Powyższe zdolności wyodrębnione przez autorki skali do badania kompetencji komunikacyjnej nawiązują do językowych sprawności komunikacyjnych opisanych przez Stanisława Grabiasa i odpowiadają za efektywne porozumiewanie się. Zdolność socjolingwistyczna odpowiada sprawności społecznej, ponieważ

${ }^{1}$ M. Kielar-Turska, M. Białecka-Pikul, Dziecko i komunikacja: lingwistyczny, społeczny i poznawczy aspekt badań, „Kwartalnik Polskiej Psychologii Rozwojowej” 1, 1993, nr 3. 
ich wspólną cechą jest umiejętność dostosowania się w rozmowie do warunków stworzonych przez społeczeństwo. Zdolność interakcyjna podobnie do sprawności sytuacyjnej wymaga od uczestnika rozmowy elastyczności w posługiwaniu się językiem i dostosowania go do otoczenia. $Z$ kolei zdolności funkcjonalne i sprawność pragmatyczna zmierzają do osiągnięcia celu wypowiedzi.

W artykule przedstawię własne narzędzie do diagnozy poziomu kompetencji komunikacyjnej dziecka z zespołem Aspergera (OKKA) w wieku wczesnoszkolnym. W opublikowanym przez mnie raporcie z badań udowodniłam, że można kształcić najdotkliwsze wśród wszystkich symptomów zespołu Aspergera zakłócenia w komunikacji werbalnej i niewerbalnej. Aby zaplanować skuteczną terapię i pomóc choremu dziecku rozwijać swój potencjał komunikacyjny, należy wcześniej zbadać, jaki jest jego poziom. Narzędzie diagnostyczne pozwoli wskazać, która z językowych sprawności komunikacyjnych realizowana jest w najmniejszym stopniu. W dotychczasowej pracy logopedycznej nie odnalazłam jednolitego testu, który pozwoliłby mi ocenić, na jakim etapie jest pacjent — co potrafi, a czego nie.

Krok po kroku przedstawię działania badającego, którym może być nie tylko logopeda, ale również nauczyciel lub rodzic pragnący pomóc dziecku rozwijać jego zdolności porozumiewawcze.

\section{Krok 1. Wywiad z rodzicami}

Rodzice są najlepszym źródłem, z którego możemy czerpać wiedzę na temat młodego pacjenta, dlatego ważne jest, aby nawiązać z nimi relację opartą na wzajemnym szacunku i zaufaniu. Wywiad jest pierwszym etapem diagnozy i służy zgromadzeniu istotnych danych o dziecku. Warto wysłuchać, co niepokoi opiekunów, oraz zapytać, czy prowadzono wcześniej terapię logopedyczną, aby nie powielać czynności terapeutycznych, które nie przyniosły sukcesu. Rozmowa z rodzicami pozwoli na obserwację środowiska, w jakim wychowuje się dziecko, oraz na ich relację. Można również zaczerpnąć wiedzę od nauczyciela wychowawcy.

\section{Krok 2. Miejsce diagnozy}

Nie można postawić diagnozy po pierwszym spotkaniu z pacjentem. Prawidłowa ocena kompetencji komunikacyjnej dziecka z zespołem Aspergera wymaga nawiązania z nim dobrego kontaktu, co może nastąpić po tygodniu lub miesiącu regularnych spotkań z logopedą. Ważne jest, aby zapewnić odpowiednie miejsce, gdzie będą odbywały się zajęcia — to może być gabinet terapeutyczny, sala w szkole, ale również dom, w którym wychowuje się dziecko. W wywiadzie z rodzicami należy ustalić, która z opcji będzie najlepsza.

Nieprawdą jest, że rodzice powinni uczestniczyć w pierwszym spotkaniu lub w ogóle w cotygodniowych zajęciach — doświadczenie podpowiada mi, iż zależy to od indywidualnych potrzeb pacjenta, ponieważ zdarza się, że obecność matki lub ojca go onieśmiela. Należy mieć na uwadze, że dziecko z zespołem Aspergera może nie polubić terapeuty i wtedy warto go zmienić. Podmiotowe podejście do diagnozy, czyli dobór odpowiedniego miejsca i uczestników, pozwala na zapewnienie przyjaznej atmosfery w czasie zajęć. 


\section{Krok 3. Aparat mowy}

Ocena budowy i sprawności narządów mownych jest bardzo ważnym krokiem $\mathrm{w}$ diagnozie i planowaniu terapii. Nieprawidłowo funkcjonujący aparat mowy uniemożliwia tworzenie dźwięków, a co za tym idzie - zdań poprawnych pod względem gramatycznym (kompetencja lingwistyczna, językowa sprawność systemowa). Poniżej wskażę narządy oraz sposób ich badania. Za wzór posłużył mi Przewodnik metodyczny do korzystania z Karty badania mowy i Kwestionariusza obrazkowego Iwony Michalak-Widery.

Tabela 1. Badanie aparatu mowy

\begin{tabular}{|l|l|}
\hline Narząd mowny & \multicolumn{1}{|c|}{ Propozycja badania } \\
\hline Język & $\begin{array}{l}\text { Uniesienie języka jak najwyżej w kierunku nosa, opusz- } \\
\text { czenie jak najniżej w kierunku brody oraz skierowanie do } \\
\text { lewego i prawego kącika ust. }\end{array}$ \\
\hline $\begin{array}{l}\text { Wędzidełko } \\
\text { podjęzykowe }\end{array}$ & $\begin{array}{l}\text { Uniesienie języka za górne zęby oraz opuszczenie w kie- } \\
\text { runku brody (ćwiczenie należy wykonywać przy otwartej } \\
\text { jamie ustnej). }\end{array}$ \\
\hline Wargi & Ułożenie ust w „dzióbek”/całus oraz przejście do uśmiechu. \\
\hline $\begin{array}{l}\text { Podniebienie } \\
\text { twarde }\end{array}$ & $\begin{array}{l}\text { Należy sprawdzić palcem przy szeroko otwartej } \\
\text { jamie ustnej, czy nie ma zbyt mocnego wgłębienia }\end{array}$ \\
\hline $\begin{array}{l}\text { Podniebienie } \\
\text { miękkie }\end{array}$ & $\begin{array}{l}\text { Należy naocznie sprawdzić, czy podniebienie miękkie jest } \\
\text { ruchome oraz czy nie są przerośnięte migdałki }\end{array}$ \\
\hline Żuchwa & $\begin{array}{l}\text { Szerokie otwarcie jamy ustnej oraz sprawdzenie szeptem } \\
\text { realizacji głoski [a] }{ }^{4} \text {. }\end{array}$ \\
\hline Zgryz & Należy naocznie zaobserwować zgryz i wykluczyć wady ${ }^{5}$. \\
\hline Uzębienie $^{\text {Należy naocznie zaobserwować stan uzębienia }}{ }^{6}$. \\
\hline Oddychanie & $\begin{array}{l}\text { Należy naocznie zaobserwować, czy sposób oddychania } \\
\text { jest prawidłowy }\end{array}$ \\
\hline
\end{tabular}

Źródło: opracowanie własne.

${ }^{2}$ Zbyt mocne wysklepienie może sugerować podniebienie gotyckie.

${ }^{3}$ Podniebienie miękkie zapobiega przedostaniu się pokarmu do części nosowej gardła. Przerośnięte migdałki mogą powodować nieprawidłowy rozwój twarzoczaszki, wady zgryzu oraz skłonność do zapalenia gardła i ucha.

${ }^{4}$ Bezgłośne opuszczenie żuchwy na około dwa centymetry sugeruje prawidłowo funkcjonującą żuchwę.

${ }^{5}$ Zgryz krzyżowy, boczne przemieszczenie żuchwy, zgryz przewieszony, przodozgryz, przodożuchwie, tyłozgryz, tyłożuchwie, zgryz otwarty, zgryz głęboki.

${ }^{6}$ Znaczna próchnica i diastema mogą powodować wady wymowy.

${ }^{7}$ Mimo iż oddychanie nie jest narządem mowy, lecz procesem wymiany gazowej, dokonującej się z ich udziałem narządów mowy, umieściłam je w tabeli 1 świadomie, w celu uporządkowania czynności w trakcie badania.

${ }^{8}$ Dziecko nie powinno mieć otwartych ust, kiedy nie mówi. Podczas wdechu nie powinny unosić się ramiona. 
Wskazane ćwiczenia warto dziecku zademonstrować. W przypadku wątpliwości lub niewiedzy należy zasięgnąć porady laryngologa, stomatologa czy ortodonty.

\section{Krok 4. Zabawa i naśladownictwo}

Diagnoza poziomu językowej sprawności sytuacyjnej, społecznej i pragmatycznej powinna odbywać się w sytuacji naturalnej, czyli takiej, która zapewni pacjentowi swobodę mówienia. Nie zachęcam do korzystania $\mathrm{z}$ gotowych materiałów obrazkowych i proszenia o nazwanie przedmiotów na nich widocznych. Proponuję zabawę, na przykład w sklep.

Tabela 2. Badanie językowej sprawności sytuacyjnej

\begin{tabular}{|l|l|}
\hline Obiekt badania & \multicolumn{1}{c|}{ Ćwiczenia diagnozujące } \\
\hline Zabawa & $\begin{array}{l}\text { Układamy na kocu zabawki — produkty spożywcze, } \\
\text { kasę fiskalną, pieniądze. }\end{array}$ \\
\hline Naśladownictwo & $\begin{array}{l}\text { 1. Podawanie produktów. } \\
\text { 2. Stukanie w kasę fiskalną. } \\
\text { 3. Wymiana pieniędzy. }\end{array}$ \\
\hline
\end{tabular}

Źródło: opracowanie własne.

Dziecko powinno zainteresować się wyłożonymi na koc przedmiotami i wziąć udział w zabawie - choć być może nie w trakcie pierwszego spotkania. Podczas zabawy należy obserwować, czy dziecko naśladuje poszczególne czynności.

\section{Krok 5. Zachowanie społeczne}

Podczas pierwszego kontaktu i późniejszej zabawy logopeda powinien zwrócić uwagę, czy pacjent dostosowuje swoje zachowanie do poznanego terapeuty.

Tabela 3. Badanie językowej sprawności społecznej

\begin{tabular}{|c|c|}
\hline Obiekt badania & Ćwiczenia diagnozujące \\
\hline $\begin{array}{l}\text { Zachowanie } \\
\text { społeczne }\end{array}$ & $\begin{array}{l}\text { 1. Patrzenie terapeucie w twarz. } \\
\text { 2. Podążanie wzrokiem za terapeutą. } \\
\text { 3. Zainteresowanie tym, co robi terapeuta. } \\
\text { 4. Stosowanie się do reguł (usiądź, podaj itp.). } \\
\text { 5. Umiejętność przywitania się i pożegnania. }\end{array}$ \\
\hline
\end{tabular}

Źródło: opracowanie własne.

Krok 6. Rozumienie i użycie języka

Aby sprawdzić, na jakim poziomie funkcjonuje językowa sprawność pragmatyczna, trzeba zaobserwować, czy pacjent rozumie, co się do niego mówi, i czy potrafi wykorzystać język do osiągnięcia celu. 
Tabela 4. Badanie językowej sprawności pragmatycznej

\begin{tabular}{|l|l|}
\hline \multicolumn{1}{|c|}{ Obiekt badania } & \multicolumn{1}{c|}{ Ćwiczenia diagnozujące } \\
\hline $\begin{array}{l}\text { Rozumienie } \\
\text { języka }\end{array}$ & $\begin{array}{l}\text { 1. Reagowanie na własne imię. } \\
\text { 2. Podawanie zabawki na polecenie. }\end{array}$ \\
\hline Użycie języka & $\begin{array}{l}\text { 1. Podejmowanie dialogu w zabawie. } \\
\text { 2. Odpowiadanie na pytania terapeuty. } \\
\text { 3. Wydawanie poleceń. }\end{array}$ \\
\hline
\end{tabular}

Źródło: opracowanie własne.

Krok 7. Spostrzeganie wzrokowe, słuchowe i sprawność manualna

Zdarza się, że za kłopoty w rozwoju kompetencji komunikacyjnej odpowiedzialny jest nieprawidłowo funkcjonujący wzrok lub słuch.

Tabela 5. Spostrzeganie wzrokowe, słuchowe i sprawność manualna

\begin{tabular}{|l|l|}
\hline \multicolumn{1}{|c|}{ Obiekt badania } & \multicolumn{1}{c|}{ Ćwiczenia diagnozujące } \\
\hline $\begin{array}{l}\text { Percepcja } \\
\text { wzrokowa }\end{array}$ & $\begin{array}{l}\text { 1. Podawanie odpowiednich produktów. } \\
\text { 2. Wkładanie i wyjmowanie z kasy pieniędzy } \\
\text { z odpowiednią cyfrą. }\end{array}$ \\
\hline Słuch fonetyczny & $\begin{array}{l}\text { 1. Oceniamy zakres słownictwa. } \\
\text { 2. Zwracamy uwagę na melodię i rytm wypowiedzi9 }\end{array}$ \\
\hline Słuch fonemowy & $\begin{array}{l}\text { 1. Zwracamy uwagę, czy dziecko różnicuje wyrazy } \\
\text { podobnie brzmiące (np. bułka - półka). }\end{array}$ \\
\hline $\begin{array}{l}\text { Sprawność } \\
\text { manualna }\end{array}$ & $\begin{array}{l}\text { 1. Odkręcanie zakrętki. } \\
\text { 2. Wrzucanie do worka artykułów spożywczych. }\end{array}$ \\
\hline
\end{tabular}

Źródło: opracowanie własne.

Obiekty badania w krokach od czwartego do siódmego wybrałam, sugerując się publikacją Jagody Cieszyńskiej, która prowadzi badania nad metodami diagnozowania dzieci z zaburzeniami komunikacji językowej ${ }^{10}$.

Zabawa z pacjentem będzie doskonałą okazją do zaobserwowania, w jaki sposób realizuje on poszczególne głoski w nagłosie, śródgłosie i wygłosie.

Wszystkie braki w wykonaniu powyższych ćwiczeń diagnozujących warto nanieść na karcie do oceny kompetencji komunikacyjnej dziecka z zespołem Aspergera (aneks) i zaplanować odpowiednią terapię. Moje wcześniejsze badanie oraz doświadczenie z pracy w gabinecie logopedycznym i w szkole, wskazują, że największy deficyt dostrzega się w rozwoju językowej sprawności społecznej.

${ }^{9}$ Melodia nie powinna być monotonna, lecz przyjemna dla słuchacza.

10 J. Cieszyńska, Wczesna diagnoza i terapia zaburzeń autystycznych. Metoda krakowska, Kraków 2010, s. 104-115. 


\section{Aneks}

\begin{tabular}{|c|c|}
\hline \multicolumn{2}{|c|}{$\begin{array}{l}\text { KARTA DO OCENY KOMPETENCJI KOMUNIKACYJNEJ } \\
\text { DZIECKA Z ZESPOLEM ASPERGERA (OKKA) }\end{array}$} \\
\hline \multicolumn{2}{|c|}{ Wywiad z rodzicami: } \\
\hline Aparat mowy: & Notatki: \\
\hline \multicolumn{2}{|l|}{ Język } \\
\hline \multicolumn{2}{|l|}{ Wędzidełko podjęzykowe } \\
\hline \multicolumn{2}{|l|}{ Wargi } \\
\hline \multicolumn{2}{|l|}{ Podniebienie twarde } \\
\hline \multicolumn{2}{|l|}{ Podniebienie miękkie } \\
\hline \multicolumn{2}{|l|}{ Żuchwa } \\
\hline \multicolumn{2}{|l|}{ Zgryz } \\
\hline \multicolumn{2}{|l|}{ Uzębienie } \\
\hline \multicolumn{2}{|l|}{ Oddychanie } \\
\hline Obiekt badania: & Notatki: \\
\hline \multicolumn{2}{|l|}{ Zabawa } \\
\hline \multicolumn{2}{|l|}{ Naśladownictwo } \\
\hline \multicolumn{2}{|l|}{ Zachowanie społeczne } \\
\hline \multicolumn{2}{|l|}{ Rozumienie języka } \\
\hline \multicolumn{2}{|l|}{ Użycie języka } \\
\hline \multicolumn{2}{|l|}{ Percepcja wzrokowa } \\
\hline \multicolumn{2}{|l|}{ Słuch fonetyczny } \\
\hline \multicolumn{2}{|l|}{ Słuch fonemowy } \\
\hline \multicolumn{2}{|l|}{ Sprawność manualna } \\
\hline Nieprawidłowo realizowane głoski: & Notatki: \\
\hline Nagłos & \\
\hline Śródgłos & \\
\hline
\end{tabular}

\section{Bibliografia}

Caban S., Ksztatcenie kompetencji komunikacyjnej dziecka z zespołem Aspergera — raport z badań, „Kształcenie Językowe” 17 (27), 2019.

Cieszyńska J., Wczesna diagnoza i terapia zaburzeń autystycznych. Metoda krakowska, Kraków 2010. Grabias S., Język w zachowaniach społecznych, Lublin 1997.

Kielar-Turska M., Białecka-Pikul M., Dziecko i komunikacja: lingwistyczny, społeczny i poznawczy aspekt badań, „Kwartalnik Polskiej Psychologii Rozwojowej” 1, 1993, nr 3.

Michalak-Widera I., Logopedyczny test dla dzieci i młodzieży, Katowice 2009. 